\title{
National Health Systems and Healthcare Contracts in the EU: a Review on the Literature over the Last 17 Years (2000-2017)
}

\author{
Bogdan STOICA ${ }^{1}$ \\ Alexandru Mihai BUGHEANU2
}

\begin{abstract}
This article presents an analysis and evaluation of the literature of the last 17 years on the studies on the National Health Systems (NHS) in the EU. On this occasion, we set as an objective to frame a systematic classification of the selected studies, which were briefly commented upon, given their large volume. It is confirmed that the NHS focuses on contracting medical services, a multi-annual phenomenon, based on national legislation, often harmonised with European legislation. From this perspective, we present a case study, namely Romania. Good contracting can be achieved by supporting guides that, although exist at an European level, are absent in many East European countries. In the last part of the article, a presentation is made-perhaps for the first time in the East-European geographical space - of these guides, wich form an integral part of the specific literature.
\end{abstract}

KEYWORDS: EU, health policies, health finance, health insurance, contracting services, health guides.

JEL CLASSIFICATION: $G 32, I 13, I 18, K 12$

\section{INTRODUCTION}

Since the nineties, after the fall of the "Iron curtain", West of Europe is facing a massive influx of immigrants from the East of the continent, and also, after the accession of 10 countries in the EU in 2004, and Romania and Bulgaria in 2007, the Western Europe faces massive labour power whose migration continues. Even today, all workers have difficult access to health services, most of the studies showing the discrimination and injustice face. (Antón \& De Bustillo, 2010; De Luca, Ponzo \& Andrés, 2013).

Currently, economically developed countries, such as Germany, opened their borders to a few millions of immigrants from Africa and the Far East. These intrusions, accepted or not, have led to the disruption of health systems in the last quarter of the century, even in the highly developed countries. Doubting that the old systems can still cope (Is Bismark dead?), it was determined the need for health reforms and also new policies enacted by the governments that improved healthcare and although they have certain similarities, are still marked of a national specificity. (Dixon \& Poteliakhoff, 2012: 4, 8; Kirchgässner, 2010: 18).

The low budgeting for health services in some East European countries is reflected in poor facilities of sanitary units. In Germany we find 290 radiotherapy centres and 221 in France, while in Croatia, Lithuania or Serbia only five to seven centres (https://dirac.iaea.org

\footnotetext{
${ }^{1}$ The Bucharest University of Economic Studies, Romania, stoica.bogdan@yahoo.com

2 The Bucharest University of Economic Studies, Romania, mihai.bugheanu@man.ase.ro
} 
/Query/Countries). To this situation is also added the unequal wages of the doctors to other professional categories which led to an exodus of tens of thousands physicians who chose to work in the West (eg. over 14.000 left Romania between 2001 and 2016, but also Bulgaria, the Czech Republic etc., $c f$. Holt, 2011: 111-112).

In turn, the East of Europe received fundings, technologies, scholarships for physicians, collaboration with doctors in the West, but perhaps the most important, a legislation which nolens volens had to harmonise with the majority. An example of this is the introduction of the European health insurance card, under the motto that "What Your Employees Don't Know Could Hurt You" (Workspan, 2002: 13), a document adopted also by the later-adhered countries. At the same time, doors were open to a new private health insurance market, but still underdeveloped and weak in the East against what would be a viable alternative to the public system (Arentz, Eekhoff \& Kochskämper, 2012).

All of these have a major influence on the types of medical services, their number and costs, and also on the contracting of these services by the state through the private or public health insurance houses with legal entities. Improving health system crises can not be achieved without good organizational, decision-making, but also contracting and risk management.

\section{THE OBJECTIVES AND METHODOLOGY OF THE RESEARCH}

The main objectives of this article are:

i. identifying studies on: the national health systems, the main legislation in this field and the guidelines for contracting medical services especially from EU member countries;

ii. achieving a systematic classification based on: the geographic criteria, the associative analysis and the number of countries concerned by the studies in question.

The Research Methodology comprised in:

i. querying databases containing scientific materials such as: JSTOR, ProQuest, Web of Science etc., but also the use, the processing and the adaptation of World Health Organization (WHO) statistics;

ii. the use of some specific keywords such as: NHS, health policies, health insurances, health providers, contract guidelines, health services, health legislation, financial instruments, health management etc.;

iii. the systematic selection and classification of those EU Health Community studies published between 2000-2017 in European or international scientific journals (eg. The European Journal of Health Economics, International Journal of Health Care Finance and Economics etc.). To be mentioned that over $90 \%$ of the explored data are drafted in English, the publication language of these journals, but also German, French and Romanian.

\section{DISCUSSION ON THE TYPOLOGY OF THE STUDIES ON THE NATIONAL HEALTH SYSTEMS IN EU, IN LITERATURE}

One approved classification of the national health systems - Niţă (2004), Văidean (2010) - is based on the method of collecting funds from insured persons, distinguishing three models:

i. Bismark, of German origin, and also the oldest model, is based on mandatory contributions depending on income (Germany, Austria, Hungary, Romania etc.);

ii. British, Beveridge model, secured from global tax funding (UK, Denmark, Sweden, Spain etc.); 
iii. the private national health insurance model based on voluntary bonuses (Bulgaria, Greece, Latvia, Cyprus).

It has been seen that none of these models is perfect, so some states are trying to add other advantageous elements to the dominant system.

Gurtner (2011: 227) noticed that since the nineties, economic health analysis begin to be centred on the needs of the patient, this being an important step in the forecasts for the correct allocation of health budget resources. Even more, recent studies conducted in Nordic countries ((Bjørner \& Arnberg, 2012: 129-143), show that there is a direct proportion between both terminally - ill patients costs and improved life expectancy, and between the same costs and future expenditure improvements in the public health sector. Since the beginning of this millennium, Breyer \& Haufler (2000: 445) proposed reforming the systems based on global tax collection by separating insurances, which can rise two advantages: the growth of compatible insurance contracts and wage-based contributions to insurance. In a different study conducted in 21 highly developed countries, one of the four conclusions raised by the authors (Okunade \& Suraratdecha, 2000: 38) is that in some EU countries, healthcare is not a necessity but neither a luxury.

The literature about the politics and health systems as well as their funding is ample. The health - human rights relation, for example, Mpinga et al. (2011), selects approx. 1000 studies from 1999-2008, of which we mention some percentages of interest: $43.7 \%$ have one author and the rest are co-written; $18.3 \%$ discuss health systems; $42.7 \%$ present social analysis; $19.8 \%$ literature review; $17.9 \%$ qualitative analysis; $34.5 \%$ have been published in public health journals; $29 \%$ in biomedical journals. Statistics from the same researchers reveal that the authors come mostly from industrialised countries, and that most studies refer to the USA (9.3\%), the second being UK (7.8\%), and lower percentages studies about Asian countries (eg: $1.9 \%$ refers to India). The conclusion was that a series of empirical studies are still needed to consolidate their field, but given the passing of a decade after the publication of that systematisation of literature, it can be said that this goal was largely fulfilled.

This finding is based on our own analysis of a dozen studies on healthcare in the EU, which we will present as further examples. Concerns in this field can be classified into five categories: monographic, general, comparative-zonal, inter-regional-comparative and comparative-intercontinental studies.

\subsection{Monographic Studies}

In the first category we may include those studies addressing health system issues from only one EU country, for example: the inequality in accessing healthcare in Belgium (Lecluyse, 2007); healthcare expenditures differences in Switzerland's cantons (Reich et al., 2012); the changing attitudes towards health and social insurance in Germany (Loh et al., 2012); the function of private health insurances in Greece (Siskou et al., 2009); healthcare package in Ireland (Smith, 2010); the perception towards health and access to health services from the perspective of gender differences in Spain (Gil-Lacruz \& Gil-Lacruz, 2010); alternative treatment in UK (Malcolm, 2008); the impact of the economic crisis on health inequalities in terms of unemployment and life expectancy in Hungary (Egedy \& Uzzoli, 2016). Such examples can continue as there is no EU country where the health field has not been reached in the literature. 


\subsection{General Studies}

The second category, that of general studies, consists of materials addressing various issues of EU health systems (funding, elderly, service providers, insurances for immigrants, services package etc.) in over 9 countries. What could be criticised is the choice of the subjectsMember States, often from developed countries, usually from the West. For example, SoléAuró, Guillén \& Crimmins (2012), Health care usage among immigrants and native-born elderly populations in eleven European countries: results from SHARE. Also: Benedict (2003) - presenting 17 EU states; McDaid (2003) - 20 states; Priebe et al. (2008) - 9 states; Schreyögg et al. (2005) - 9 states; Tubeuf \& Jusot (2011) - 11 states a.o.

\subsection{Comparative-Zonal Studies}

The third category consists of the comparative-zonal materials in which the countries in a certain area are studied. These types of studies make it possible to identify strategies that are similar and even transcended to the target group of countries. Authors have to take into account the regional culture in order to create a solid framework if they want to explain as many distinctive solutions as they can find in the health systems of that area (Saltman, 2012: 13). We can illustrate this with a study of the same author mentioned above, which examines the policies and health systems in the Nordic group: UK, Denmark, Sweden and tangential Norway (Saltman, 2015: 455-459). On the other side of Europe, we can easily see the constant concerns of some native East, such as Jakovljevic (2013), who publishes a relevant analysis of health financing strategies in the countries of the former Yugoslavia. Many other studies, often empirical, were co-authored (sometimes over six authors, both from Eastern and the Western Europe or the United States). For example, Waters et al. (2008) presents the trends, challenges and differences in the coverage of health insurance in the 10 countries that joined the EU in 2004-2007 (Czech Republic, Slovakia, Slovenia, Romania, Bulgaria etc.), systems that - according to the authors - have evolved differently, although they started from a common denominator: the former communist space.

\subsection{Inter-Regional-Comparative Studies}

The fourth category - in our opinion, the most valuable - represents the inter-regionalcomparative studies, seldom published due to their complexity. A study that deals with health issues in the paradigm of the social security reforms, starting from the idea that differences between the welfare of the West and the gaps of the East give rise to preferential policies, is the one signed by Velladics, Henkens \& Van Dalen (2006). Only in such inter-regional comparisons can be seen examples, developments and loans between different EU areas, where, in the field of social and private health insurance, the less experienced can learn from those with successful experiences.

\subsection{Comparative-Intercontinental Studies}

The last category of studies is the comparative-intercontinental one, which compares health systems in Europe with systems in America, Australia etc. Blomqvist \& Busby (2012) speaks about the lessons that Canadians need to learn - "European Lessons for Canada" - on the use of effective tools for spending health resources from Europeans, especially from the British and the Dutch. At the same time, Kurzer (2008) has launched for almost a decade the question "Is Europe subject to Americanisation?", referring to the policies of the European Commission in collaboration with the WHO, implemented with the help of NGOs, in the fight against tobacco, obesity, incorrect diet etc. In fact, there is an increase in the regional 
empirical studies that present extremely valuable data from the perspective of so-called health risk factors, and WHO statistics are used globally (eg.: http://www.who.int/gho/tobacco/en/).

\section{DISCUSSION ON THE LEGISLATION IN THE HEALTH FILED, AS PRESENTED IN LITERATURE}

\subsection{European Countries Case}

In the last century, legislation played a fundamental role in improving global public health, so some researchers (Burris, 2017) created the concept of PHLR (Public Health Law Research), the framework which studies the circumstances and to what extent the legislation affects public health. Burris recommends an interdisciplinary approach: science, health, legislation, and a number of logical models of this kind of research, focused on the effect of law. A whole range of issues related to patients rights, equality before the law, access to medical services, malpractice etc. have been monitored in the light of the jurisprudence of the European Court of Human Rights, the most important document drawn up in 2002 under the auspices of the WHO, The European Charter of Patients' Rights (Di Costanzo, 2012: 84). Since joining the $\mathrm{EU}$, the former communist countries have been obliged to ratify most of Europe's treaties, agreements and European conventions on health.

An example is in Romania, G.D. no. 304/2014, the approval of Methodological Norms on cross-border healthcare. Another example is the introduction in all healthcare contracts, such as health insurance companies and suppliers, the compulsory (based on the principle of reciprocity) in the provision of medical services to foreigns who benefit from European documents issued in application of European Commission Regulation no. 883/2004 of the European Parliament and the European Council. However, recent information shows that Romania reimburses over $€ 500$ million for Romanians treatments abroad, which would represent $2 / 3$ of the costs of building a regional hospital, so "European countries are complaining of migration, but not of the migration of patients who bring heavy money" (Vulcănescu cit. de Bolojan, 2017).

But, besides the European legislation, there is also a national legislation. As an answer to the question: "EU law and national health policies: problem or opportunity?", Prof. T.K. Hervey (2007: 6) thinks that for the Member States the European legislation is the opportunity for all states to achieve that "European social model", a free-of-charge health service and in a law context competition, by protecting those values and the fundamental principles. In fact, the constitutions of the modern states guarantee the fundamental right to life, health and integrity, and other authors have successfully demonstrated the improvement of the quality of health care due to that "competition law" among healthcare providers (Fornaciari, 2010).

Using questionnaires, based on 20 indicators in the health field, the WHO calculates annually the percentage of each country as regards the appropriate legal framework to support the implementation of health policies through national structures, the responsibilities of the state authorities and the appropriate allocation of budget health resources. In such a statistic, which we have done for ex-communist countries based on the average of the last 5 years, Romania has a "middle place", as can be seen from the table below.

Table 1. The Score on the Implementation of Health Policies in 11 Ex-Communist Countries (2012-2016)

\begin{tabular}{|c|c|c|c|c|c|c|}
\hline & Countries & $\mathbf{2 0 1 6}$ & $\mathbf{2 0 1 5}$ & $\mathbf{2 0 1 4}$ & $\mathbf{2 0 1 3}$ & $\mathbf{2 0 1 2}$ \\
\hline 1 & Czechia & 100 & 100 & 100 & 100 & 100 \\
\hline 2 & Lithuania & 100 & 100 & 100 & 100 & 100 \\
\hline 3 & Slovakia & 100 & 100 & 100 & 100 & 100 \\
\hline
\end{tabular}




\begin{tabular}{|c|c|c|c|c|c|c|}
\hline & Countries & $\mathbf{2 0 1 6}$ & $\mathbf{2 0 1 5}$ & $\mathbf{2 0 1 4}$ & $\mathbf{2 0 1 3}$ & $\mathbf{2 0 1 2}$ \\
\hline 4 & Slovenia & 100 & 100 & 100 & 100 & 100 \\
\hline 5 & Hungary & 100 & 100 & 75 & 100 & 100 \\
\hline 6 & Latvia & 100 & 100 & 100 & & 100 \\
\hline 7 & Romania & 75 & 75 & 75 & 50 & \\
\hline 8 & Croatia & 50 & 50 & 50 & 100 & 5 \\
\hline 9 & Poland & 50 & & 50 & 50 & 25 \\
\hline 10 & Estonia & 25 & 25 & 25 & 25 & \\
\hline 11 & Bulgaria & & & 75 & & \\
\hline
\end{tabular}

Source: Adapted from

http://apps.who.int/gho/data/view.main.IHRCTRY01v?lang=en

\subsection{Romania}

In Romania, the public health field is coordinated by the main legislation, the Law no. $95 / 2006$ on health reform, republished in 2015 , which enclose the basic principles, the rights and obligations of the insured, after the rights of the patients were former monitored by the Law no. 46/2003.

In regards to the contracting of the medical services, the Government issues annually an agreement approving the medical services packages, the framework contract, and also establishes the conditions for the provision of medical care, medicines, medical devices and medical services (in force is G.D. no. 161/2016). The Ministry of Health (MOH) and the National Health Insurance House (NHIH) issue rules of application by the Health Insurance Houses (HIHs) in the territory of the decision in question (the MOH/NHIH/196/139/2017 Order).

There is, of course, an entire secondary legislation which, during the enactment of these normative acts, complements and/or amends them. It should be mentioned that according to this German-French model legislation, the health insurance contributions paid to the National Agency for Fiscal Administration (NAFA), respectively the allocated budgets, as well as the health services and their contracting, are presented according to the next scheme.

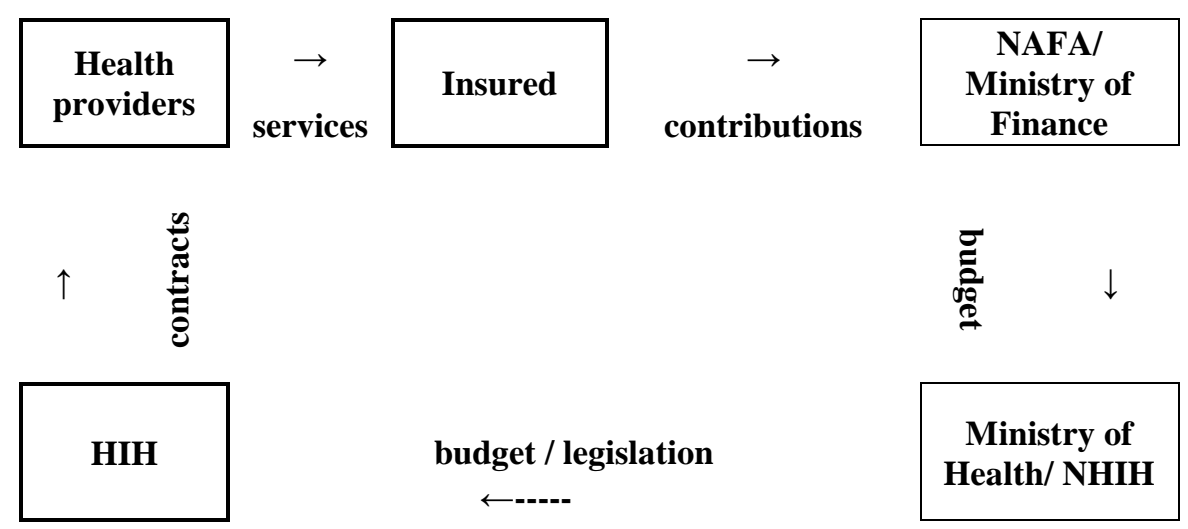

Figure 1. The Circuit of Financing-Contracting Medical Services in Romania Source: Adapted from the current legislation

\section{LITERATURE CONCERNING THE CONTRACTING GUIDELINES OF MEDICAL SERVICES}

At a practical level, it seems that literature is less useful when we speak about contracting health services, as it is rather used in research. Also, the wide-ranging legislation, which is constantly changing - a fact that does not create stability - falls within the hands of the 
institutions whose officials are obliged to know about it in order to be able to apply it, but at the same time, it must also be known by the healthcare suppliers in order to meet the contracting conditions. In support of the last two categories, several contracting guidelines have been developed.

For the low and middle income countries, among the first contracting guideline is the one of England (2000). Some of the proposals have been taken over by Latin American countries, with the note that this guideline is taken as an example by the NHS in the UK. The author principally discuss about the contracting process, listing possible parts of the contract (eg social health insurance companies - private health providers). He approached the poor, the effectiveness and efficiency of the cost of medical services, the annual budget allocation plan, the expected performance, what a contract should comprise, the framework model etc. One of the most important aspects is that England explains a number of problems that may occur during the contracting period.

Another guide, of Anglo-Saxon origin, defines the contract as being: a written agreement between two parties, inforced by legislation, regulatory, by which government funds are transferred to a contractor in return for quality services provided in the text of the contract. After Abramson's model (2004), from where the definition has been taken over and the title of the guide has been completed with "A Manual for Policy Makers", the utility of its tool lies in: helping the public health sector understand the meaning of contracting, to fulfil its target, to determine the most relevant services, target groups etc., in one word to raise the quality of public health. Systematically and synthetically the author explains what the contract is, the legal framework on which it is concluded, the choice of health providers, expenses, the settlement of accounts mechanism, some advantages and disadvantages of the contract and even the possible risks.

Most of the themes discussed in the above-mentioned papers can be found in the written guide co-authored by Liu et al. (2004: xiii, eg. the definition of contracting is taken from England, 2000). Researchers present a short history of the matter, a part of the literature on the topic (Nota bene! - two Romanian authors are also quoted: Vlădescu \& Rădulescu), but noteworthy is the fact that in both the subchapter on evidences of effects and the one based on the impact is highlighted the access, quality, equity and efficiency of the health services provided.

For the developing countries, Loevinsohn (2008) established the concept of PBC (Performance-Based Contracting for Health Services), presenting a set of instruments. The first two chapters are devoted to a PBC background, explaining and deepening the concept. The third chapter is highlighted because it logically lists the stages of contracting: the conduct of the dialogue with stakeholders, the definition of services, the monitoring and evaluation framework, the selection of contractors and price settlement, the contracting management, the preparation of the price offer etc. The work also includes a rich bibliography in the field, part of which is found in parallel, analysed on this occasion by us.

Because we above mentioned the instruments for developing countries, it must be said that even the less developed countries have health service contracting guidelines, and on this occasion we will only mention two, existent on the Black Continent. Guide opérationnel pour la contractualisation dans le Secteur de la Santè au Tchad, Ministère de la Santè Publique, 2003, with the support of the WHO and the World Bank, used for the purpose of relevant and effective contracting and improvement of services in the healthcare sector, as stated in the 
preface. From all the five chapters, groundbreaker is the one presenting the 12 characteristics required for a successful contracting, emphasising the legal, ethical and moral obligations. Much more developed is the one published by D. Mudenda and four other authors at the University of Zambia, funded by the Rockefeller Foundation: Provider of Purchasing and Contracting for Health Services: Case of Zambia (2008).

We end this intervention with the one who is the de facto artisan of contracting healthcare services at a WHO level, Jean Perrot, who chronologically listed a part of his contributions to the field for more than a decade. The first identified material has been prepared towards the contracting for developing countries, co-authored, emphasising the market economy, the state and health activities, contract theories, clauses, negotiation, contracting strategies etc. (Perrot, Carrin \& Sergent, 1997). Perrot (2006) also dedicated a research to contracting healthcare systems in developed countries - the OECD. Also, studies towards the allocation of budgetary resources in health (Perrot, 2002) or the relationship between correct contracting and the performance of the health system (Perrot, 2004, 2005, 2010), are strictly related to contracting. In 2007, the author framed a Vade-mecum de la contractualisation dans le secteur de la santé and a [Une politique nationale de contractualisation] Guide pour son elaboration et son suivi, in which, besides theoretical elements, he addressed pragmatic issues: the public-private partnership, the franchise, networks or other topics of interest.

\section{CONCLUSIONS}

The challenges that the EU had to deal with at a rapid pace in the past two decades are both negative (labor migration, non-European migrants etc.) and positive (telemedicine, nanomedicine or other high-tech medical technologies, scientific exchanges etc.), these being also the causes of reforming health systems, especially in developed countries. Although the differences between the East and West of Europe seem to have improved, the EU member states that have joined later are advancing with sanitary reforms, following a recently established expression: "with the second speed".

A unitary health system is still far from being achieved as long as national identities are still present in national legislations, and it is not yet possible to speak of the perfect system, but rather of erasing the old health system. It can rise a problem to a potential unification and centrifugal trends in some regions of the EU: Catalonia, Lombardia and others.

As far as literature is concerned, we consider that the most important studies for the eastern countries are indeed those comparative studies between the East and the West. The influence of the EU as a supra-state entity is indisputable in the scientific realm, a fact found in the multitude of central journals in which the latest theories, pragmatic studies, analysis and statistics in the field of economy, policies and legislation on health are published. On the case study on Romanian legislation, it should be highlighted that the country is politically influenced, so various aspects of substance change on average every two years. The legislation is issued with a remedy for the deficiencies found at present and coming from previous years, and not for the purpose of preventing them.

In fact, most eastern states carry out contracting processes on the basis of methodologies and strategies, but not on the basis of a unitary EU-wide guide. Even though some of the contracting guidelines or, better to say, some aspects of them are out of date and inapplicable 
today, these tools remain an example of good practice. In addition to contracting their review would certainly contribute to a higher level of performance in the public health sector.

\section{ACKNOWLEDGEMENT}

This study was counducted through the post-doctoral advanced research studies for the academic years 2018-2020, Management field, coordinator The Bucharest University of Economic Studies".

\section{REFERENCES}

Abramson, W.B. (2004). Contracting for health care service delivery. A Manual for Policy Makers, Boston MA: John Snow Inc.

Antón, J.I. \& De Bustillo, R.M. (2010). Health care utilisation and immigration in Spain. The European Journal of Health Economics, (11), 487-498. DOI: 10 1007/s 10198-009-0204-z

Arentz, Ch., Eekhoff, J. \& Kochskämper S. (2012). Private health insurance: a role model for European health systems. The European Journal of Health Economics, (13), 615-621. DOI: 10. 1007/s 10198-012-0406-7

Benedict, I. (2003). Funding health care: Alternatives to the NHS. Consumer Policy Review, 13 (4), 118-126

Bjørner, Th. B. \& Arnberg, S. (2012). Terminal costs, improved life expectancy and future public health expenditure. International Journal of Health Care Finance and Economics, (12), 129-143. DOl: 1 0.1007/s 10754-0 12-9 106-1

Blomqvist, A. \& Busby, C. (2012). Better Value for Money in Healthcare: European Lessons for Canada, Toronto, C.D. Howe Institute, Commentary No. 339, January 2012

Breyer, F. \& Haufler A. (2000). Health Care Reform: Separating Insurance from Income Redistribution. International Tax and Public Finance (Aug. 2000), 7(4-5), 445-461

Bolojan, B. (2017). CNAS, decontare străinătate. România pierde sute de milioane de euro, Retrieved October 16, 2017 from https://www.dcnews.ro/cnas-decontare-strainatateromania-pierde-sute-de-milioane-de-euro_561891.html

Burris, S. (2017). Scientific evaluation of law's effects on public health. Canberrra: ANU Press

De Luca, G., Ponzo M. \& Andrés A.R. (2013). Health care utilization by immigrants in Italy. International Journal of Health Care Finance and Economics, 13, (1) (March 2013), $1-31$

Di Costanzo, C. (2012). Science and rights: the 'clinical reasoning' within health needs assessment. International Journal of Law and Social Sciences, 1, (2), (July 2012), 84-89

Dixon, A. \& Poteliakhoff, E. (2012). Back to the future: 10 years of European health reforms. Health Economics, Policy and Law, (7), 1-10. DOI:10.1017/S1744133111000247

Egedy, T. \& Uzzoli, A. (2016). Cities as the keys to survival? The impact of the economic crisis on health inequalities in Hungary in terms of unemployment and life expectancy. Urbani Izziv, Vol. 27, No. 2 (December 2016), 97-111

England, R. (2000). Contracting and Performance Management in the Health Sector, A Guide for Low and Middle Income Countries, DFID Health Systems Resource Centre, UK Department for International Development by the Institute for Health Sector Development, London. EU to create health insurance card for workers (2002). Workspan, 45(6), p. 13

Fornaciari, D. (2010). Quality Health Care in the European Union Thanks to Competition Law. International Journal of Environmental Research and Public Health, (7), 1-8. doi:10.3390/ijerph7010001 
Gil-Lacruz, M. \& Gil-Lacruz, A. I. (2010). Health Perception and Health Care Access: Sex Differences in Behaviors and Attitudes. The American Journal of Economics and Sociology, Vol. 69, No. 2 (April, 2010), 783-801

Gurtner, S. (2013). An analysis of the influence of framework aspects on the study design of healtheconomic modeling evaluations. The European Journal of Health Economics, Vol. 14, No. 2 (April 2013), 221-230

Hervey, T.K. (2007). EU law and national health policies: problem or opportunity? Health Economics, Policy and Law, (2), 1-6. DOI:10.1017/S1744133106006219

Holt, E. (2011, January 8). Czech doctors resign en masse. The Lancet, pp. 111-112

Jakovljevic, M. B. (2013). Resource allocation strategies in Southeastern European health policy. The European Journal of Health Economics, 14 (2) (April 2013), 153-159

Kirchgässner, G. (2010). Die Einführung der Gesundheitsprämie: Eine wirkliche Reform? Ifo Schnelldienst, (Aug 27, 2010), 63(16), 16-18

Kurzer, P. (2008). Public Health in the EU: Is Europe subject to Americanization? German Policy Studies, 4(1), 1-45

Lecluyse, A. (2007). Income-related health inequality in Belgium: a longitudinal perspective. The European Journal of Health Economics, 8 (3), (Sept. 2007), 237-243

Liu, X., Hotchkiss, D., Bose, S., Bitran, R. \& Giedion, U. (2004). Contracting for Primary Health Services: Evidence on Its Effects and Framework for Evaluation. Bethesda, MD: The Partners for Health Reformplus Project, Abt Associates Inc.

Loevinsohn, B. (2008). Performance-Based Contracting for Health Services in Developing Countries: A Toolkit. The International Bank for Reconstruction and Development / The World Bank, Washington DC. doi: 10.1596/978-0-8213-7536-5

Loh, C.-P. A., Nihalani, K. \& Schnusenberg, O. (2012). Measuring attitude toward social health insurance. The European Journal of Health Economics, 13(6) (December 2012), 707-722

Malcolm, D. (2008, September 15). Alternatives to treatment in the UK. The Lancet, p. 479

McDaid, D. (2003). Who pays? Approaches to funding healthcare in Europe. Consumer Policy Review, 13 (5), (Sep/Oct 2003), 166-172

Ministère de la Santé Publique (2003). Guide opérationnel pour la contractualisation dans le Secteur de la Santé au Tchad, Tchad

Mpinga, E.K., Verloo, H., London, L. \& Chastonay Ph. (2011). Health and human rights in scientific literature: A systematic review over a decade (1999-2008). Health and human rights, 13 (2), (December 2011), 102-129

Mudenda, D., Mapoma, Ch., Chita, B., Chompolola, A. \& Wake, W. (2008). Provider Purchasing and Contracting for Health Services: Case of Zambia, University of Zambia Economics Department

Niţă, L. (2004). Politica socială în Uniunea Europeană, Editura Universitaria, Craiova

Okunade, A.A. \& Suraratdecha, Ch. (2000). Health care expenditure inertia in the OECD countries: A heterogeneous analysis. Health Care Management Science, (3), 31-42

Perrot, J., Carrin, G. \& Sergent, F. (1997). L'aproche contractuelle: de nouveaux partenariats pour la santé dans les pays en développement. OMS-Geneve, Document technique, No. 24, Série Macroéconomie, santé et développement

Perrot, J. (2002). Analyse de l'allocation des ressources financières au sein d'un système de santé. OMS-Geneve, Discussion paper, No. 1

Perrot, J. (2004). Le role de la contractualisation dans l'amélioration de la performance de système de santé. OMS-Geneve, Discussion paper, No. 1

Perrot, J. (2005). Le recours à la contractualisation dans les systèmes de santé. Principaux messages. OMS-Geneve, Résumés techniques pour décideurs, No. 4 
Perrot, J. (2006). La contractualisation dans les systèmes de santé des pays de l'OCDE. OMSGeneve, Discussion paper, No. 4

Perrot, J. (2007). Vade-mecum de la contractualisation dans le secteur de la santé. OMSGeneve, Discussion paper, No. 1

Perrot, J. (2007). Une politique nationale de contractualisation. Guide pour son elaboration et son suivi. OMS-Geneve, Discussion paper, No. 2

Perrot, J. (2010). L'incitation a la performance des prestataires de services de santé. OMS, Discussion paper, No. 1

Priebe, S., Patrick, F., Gaddini, A., Kilian, R., Lauber, Ch., Martinez-Leal, R. et al. (2008). Mental Health Care Institutions in Nine European Countries, 2002 to 2006. Psychiatric Services, 59 (5) (May 2008), 570-573

Reich, O., Weins, C., Schusterschitz, C. \& Thöni, M. (2012). Exploring the disparities of regional health care expenditures in Switzerland: some empirical evidence. The European Journal of Health Economics, 13 (2) (April 2012), 193-202

Saltman, R. B. (2012). The role of comparative health studies for policy learning. Health Economics, Policy and Law, (7), 11-13. DOI:10.1017/S1744133111000259

Saltman, R. B. (2015). Reflecting on 'Choice policies in Northern European health systems. Health Economics, Policy and Law, (10), 455-459. doi:10.1017/S1744133115000213

Schreyögg, J., Stargardt, T., Velasco-Garrido, M. \& Busse, R. (2005). Defining the "Health Benefit Basket" in nine European countries. The European Journal of Health Economics, [Suppl 1] (November 2005), (6), 2-10. DOI 10.1007/s10198-005-0312-3

Siskou, O., Kaitelidou, D., Economou, Ch., Kostagiolas P. \& Liaropoulos, L. (2009). Private Expenditure and the Role of Private Health Insurance in Greece: Status Quo and Future Trends. The European Journal of Health Economics, 10 (4), 467-474

Smith, S. (2010). The Irish "health basket": a basket case? The European Journal of Health Economics, 11 (3), 343-350

Solé-Auró, A., Guillén, M. \& Crimmins E. M. (2012). Health care usage among immigrants and native-born elderly populations in eleven European countries: results from SHARE. The European Journal of Health Economics, 13 (6), 741-754

Tubeuf, S. \& Jusot, F. (2011). Social health inequalities among older Europeans: the contribution of social and family background. The European Journal of Health Economics, Vol. 12, (1), 61-77

Văidean, V.-L. (2010). Asigurările sociale de sănătate în România - realităţi şi perspective (teză de doctorat nepublicată, Universitatea "Babeş-Bolyai", Cluj-Napoca, 2010). Retrieved October 10, 2017 from http://doctorat.ubbcluj.ro/sustinerea_publica/rezumate /2010/finante/Vaidean_Viorela_RO.pdf

Velladics, K., Henkens, K. \& Van Dalen, H.P. (2006). Do different welfare states engender different policy preferences? Opinions on pension reforms in Eastern and Western Europe. Ageing \& Society, (26), 475-495. doi:10.1017/S0144686X05004551

Waters, H.R., Hobart, J., Forrest, Ch.B., Siemens, K.K., Pittman, P.M., Murthy A. et al. (2008). Health Insurance Coverage in Central and Eastern Europe: Trends and Challenges. Health Affairs, 27(2), 478-486. doi: 10.1377/hlthaff.27.2.478 